\title{
TOBACCO USE AND \\ PUBLIC HEALTH
}

Federal Efforts to

Prevent and Reduce

Tobacco Use among

Youth

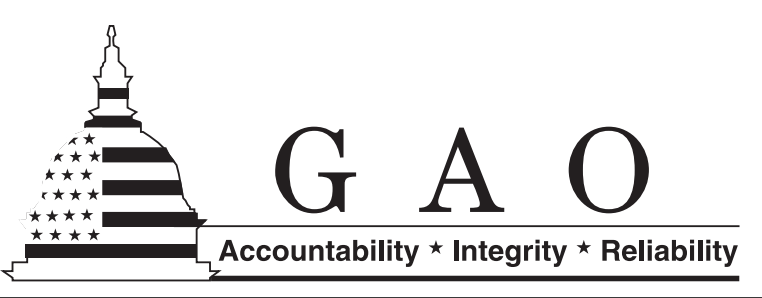




\section{G A O Accountability•Integrity- Reliability Highlights}

Highlights of GAO-04-41, a report to the Honorable Bill Frist, U.S. Senate

\section{TOBACCO USE AND PUBLIC HEALTH}

\section{Federal Efforts to Prevent and Reduce Tobacco Use among Youth}

\section{What GAO Found}

Some federal programs, research, and activities that aim to address tobacco use among youth focus only on tobacco while others aim to address tobacco use as part of broader efforts to address unhealthy behaviors such as substance abuse and violence. Two federal programs within the Department of Health and Human Services (HHS) focus only on tobacco use. CDC's National Tobacco Control Program (NTCP) focuses on preventing and reducing tobacco use among the general population and explicitly targets youth. The Substance Abuse and Mental Health Services Administration's program to oversee implementation of a provision of federal law, commonly referred as the Synar Amendment, focuses only on tobacco use among youth. The Synar Amendment requires states to enact and enforce laws prohibiting the sale of tobacco products to minors. In addition to these tobacco-focused programs, HHS, and the Departments of Defense (DOD), Justice (DOJ), and Education sponsor programs that include tobacco use as part of broader efforts to address unhealthy behaviors among youth, such as substance abuse and violence. For example, Education's Safe and Drug-Free Schools and Communities program is designed to prevent substance abuse and violence. HHS agencies, such as the National Institutes of Health, conduct research on tobacco use and nicotine addiction among youth and its health effects on youth. HHS agencies and other federal departments also support activities to prevent and reduce tobacco use among youth, such as education and outreach efforts. HHS and its component agencies coordinate tobacco-related efforts with other federal, state, and local government agencies and nongovernmental entities.

GAO was asked to provide information on federal efforts to prevent and reduce youth smoking. Specifically, this report describes (1) federal programs, research, and activities that aim to prevent and reduce tobacco use among youth, (2) the efforts of federal departments and agencies to monitor their programs, and (3) the coordination among federal departments and agencies in efforts to prevent and reduce tobacco use among youth.
Federal departments and agencies collect a variety of information to monitor how programs that aim to address tobacco use among youth are being implemented by grantees and the effectiveness of grantee efforts in meeting program goals. The information is collected through various means, including grant applications, progress reports, periodic site visits, and program evaluations. For example, to monitor NTCP, CDC requires states to submit biannual reports on the implementation of state NTCP-supported tobacco control programs. The information that federal departments and agencies collect on these programs is also used to provide training and technical assistance to grantees on topics such as conducting program evaluation.

In commenting on a draft of this report, HHS stated that the report was very informative but it did not include programs like Medicaid that are a substantial element of HHS tobacco prevention efforts. Including programs that finance health insurance such as Medicaid, however, was beyond the scope of our review. Also, HHS noted that we did not include information about the challenges other federal agencies face in coordinating tobaccorelated issues but DOD, DOJ, and Education did not describe such challenges. DOD and DOJ had no comments on the report and HHS and Education provided technical comments that we incorporated as appropriate. 


\section{Contents}

\section{Letter}

Results in Brief

Background

Some Federal Programs, Research, and Activities Focus Only on

Tobacco Use, While Others Address Tobacco Use Along with

Other Unhealthy Behaviors

Federal Departments and Agencies Collect a Variety of Information on Their Programs That Aim to Prevent Tobacco Use among Youth

Federal Departments and Agencies Coordinate in Various Ways to Address Tobacco Use among Youth

\begin{tabular}{ll}
\hline Appendix II & Selected Federal Programs That Address or Can \\
Address Tobacco Prevention and Reduction among \\
Youth
\end{tabular}

\section{Appendix III}

\section{Comments from the Department of Health and Human Services}

Appendix IV

\section{Tables}

Table 1: Examples of Federal Collaborative Education and Outreach Activities to Address Tobacco Use among Youth 


\section{Figure}

Figure 1: Estimated Rate of Current Smoking among 8th, 10th, and 12th Grade Students, 1991-2002

\section{Abbreviations}

$\begin{array}{ll}\text { AHRQ } & \text { Agency for Healthcare Research and Quality } \\ \text { CDC } & \text { Centers for Disease Control and Prevention } \\ \text { CMS } & \text { Centers for Medicare \& Medicaid Services } \\ \text { DEFY } & \text { Drug Education for Youth Program } \\ \text { DOD } & \text { Department of Defense } \\ \text { DOJ } & \text { Department of Justice } \\ \text { EPA } & \text { Environmental Protection Agency } \\ \text { HHS } & \text { Department of Health and Human Services } \\ \text { HRSA } & \text { Health Resources and Services Administration } \\ \text { IHS } & \text { Indian Health Service } \\ \text { NCI } & \text { National Cancer Institute } \\ \text { NHLBI } & \text { National Heart, Lung, and Blood Institute } \\ \text { NICHD } & \text { National Institute of Child Health and Human Development } \\ \text { NIDCR } & \text { National Institute of Dental and Craniofacial Research } \\ \text { NIDA } & \text { National Institute on Drug Abuse } \\ \text { NIH } & \text { National Institutes of Health } \\ \text { NTCP } & \text { National Tobacco Control Program } \\ \text { ONDCP } & \text { Office of National Drug Control Policy } \\ \text { SAMHSA } & \text { Substance Abuse and Mental Health Services } \\ & \text { Administration } \\ \text { TTURCs } & \text { Transdisciplinary Tobacco Use Research Centers }\end{array}$

This is a work of the U.S. government and is not subject to copyright protection in the United States. It may be reproduced and distributed in its entirety without further permission from GAO. However, because this work may contain copyrighted images or other material, permission from the copyright holder may be necessary if you wish to reproduce this material separately. 
November 21, 2003

The Honorable Bill Frist

United States Senate

Dear Senator Frist:

Tobacco use is the leading cause of preventable death in the United States. In its most recent estimates of selected health consequences of cigarette smoking, the Centers for Disease Control and Prevention (CDC) reported that, on average, over 440,000 deaths and $\$ 76$ billion in medical expenditures were attributable to cigarette smoking each year from 1995 through 1999. ${ }^{1}$ Reducing the number of tobacco-related deaths, along with the associated costs, represents a significant public health challenge for the federal government. The first Surgeon General's report to the Congress that specifically focused on tobacco use among youth concluded that preventing youth from starting to use tobacco is key to reducing the deaths and incidence of disease attributable to tobacco use. ${ }^{2}$ Most adults who use tobacco started using it between the ages of 10 and 18. According to the report, if children and adolescents can be encouraged to abstain from using tobacco before they become adults, they are less likely to use tobacco for the rest of their lives. Although smoking rates (defined as smoking one or more cigarettes in the previous 30 days) among 12 th grade students have declined from a rate of about 37 percent in 1997, in 2002, about 27 percent of 12 th grade students reported that they smoked. In 1992, the Congress passed legislation, commonly referred to as the Synar Amendment, designed to prohibit the sale and distribution of tobacco products to minors. $^{3}$

\footnotetext{
${ }^{1}$ Centers for Disease Control and Prevention, “Annual Smoking-Attributable Mortality, Years of Potential Life Lost, and Economic Costs - United States, 1995-1999," Morbidity and Mortality Weekly Report, vol. 51, no. 14 (2002) 300-303. The Morbidity and Mortality Weekly Report disseminates information about the public health issues in which CDC is involved.

${ }^{2}$ U.S. Department of Health and Human Services, Preventing Tobacco Use Among Young People: A Report of the Surgeon General (Atlanta, Ga.: Centers for Disease Control and Prevention, 1994).

${ }^{3}$ The Synar Amendment is found in $\$ 1926$ of the Public Health Service Act as added by the Drug Abuse and Mental Health Administration Reorganization Act, Pub. L. No. 102-321 § 202, 106 Stat. 394 (1992) (classified to 42 U.S.C. § 300x-26 (2000)).
} 
Given the harmful effects of tobacco use and the rates of smoking among youth, ${ }^{4}$ you asked us to provide information on federal efforts to prevent and reduce youth smoking. We focused our review on describing (1) programs, research, and activities that aim to prevent and reduce tobacco use among youth, (2) the efforts of federal departments and agencies to monitor their programs, and (3) the coordination among federal departments and agencies in their efforts to prevent and reduce tobacco use among youth.

To identify federal programs, research, and activities ${ }^{5}$ that aim to address tobacco use among youth, we reviewed the Catalog of Federal Domestic Assistance, which is a database of federal grant programs, ${ }^{6}$ and other pertinent documents. In addition, we interviewed program officials in multiple federal agencies. ${ }^{7}$ As a result, we focused on four federal departments that support programs and other efforts to prevent and reduce tobacco use among youth: the Department of Health and Human Services (HHS) and its component agencies_CDC, Substance Abuse and Mental Health and Services Administration (SAMHSA), National Institutes of Health $(\mathrm{NIH})$, and Health Resources and Services Administration (HRSA); the Department of Defense (DOD); the Department of Justice (DOJ); and the Department of Education (Education). Where available, we also obtained fiscal year 2002 funding information on the federal programs and research that we identified. To identify how federal departments and agencies monitor their programs, we reviewed agency strategic plans, annual performance plans and reports, program guidance documents, and program evaluations. To determine how federal departments and agencies coordinate their efforts, we reviewed their strategic plans and annual performance plans and reports and also descriptions of coordination efforts. In addition, we interviewed agency officials about their program monitoring and coordination efforts and asked them to describe any coordination challenges they faced. (For additional information on our methodology, see app. I.) We conducted our work from January 2003

\footnotetext{
${ }^{4}$ For the purposes of this report, youth refers to children and adolescents under the age of 18 .

${ }^{5}$ In this report, the term "activities" refers to federal efforts to prevent and reduce tobacco use among youth, such as education and outreach and training and technical assistance.

${ }^{6}$ The General Services Administration maintains this database.

${ }^{7}$ The scope of our work did not include programs that finance health insurance such as Medicaid.
} 
through October 2003 in accordance with generally accepted government auditing standards.

Some federal programs, research, and activities that address tobacco use among youth focus only on tobacco use, while others aim to prevent and reduce tobacco use as part of broader efforts to address unhealthy behaviors like substance abuse and violence. We identified two federal programs that focus only on tobacco use. These programs are within HHS, the lead federal department for addressing public health issues related to tobacco. The first program, CDC's National Tobacco Control Program (NTCP), provides funds through cooperative agreements to state tobacco control programs to prevent and reduce tobacco use among youth and adults. The second tobacco program, SAMHSA's program to oversee implementation of the Synar Amendment, is the only federal program we identified that focuses only on tobacco use among youth. The Synar Amendment requires states to enact and enforce tobacco control laws to prevent individuals under the age of 18 from purchasing tobacco products. In addition to these tobacco-focused programs, HHS, Education, DOJ, and DOD sponsor programs that aim to address tobacco use among youth as part of broader efforts to prevent unhealthy behaviors, such as substance abuse and violence. For example, Education's Safe and Drug-Free Schools and Communities program supports state efforts to create learning environments in the nation's schools that are free of violence and drug use, including tobacco. HHS agencies also conduct research on tobacco use among youth. For example, NIH supports research projects to examine the factors influencing both tobacco use and nicotine addiction among youth and assesses interventions designed to prevent and help youth quit tobacco use. HHS agencies and other federal departments also support activities to prevent and reduce tobacco use among youth, such as education and outreach efforts.

To monitor their programs that aim to prevent and reduce tobacco use among youth, federal departments and agencies collect a variety of information on how their programs are being implemented by grantees and the effectiveness of grantees' efforts in meeting national program goals. This information is obtained from such sources as grant applications, grantee progress reports, periodic site visits, and program evaluations. In fiscal year 2003, CDC took steps to obtain additional information on the design, implementation, and effects of state tobacco control programs. For example, CDC now requires that states submit more detailed information in their biannual reports and dedicate staff to evaluate their individual tobacco control programs. Other federal 
departments and agencies obtain information on the efforts and effectiveness of their programs that aim to prevent and reduce smoking among youth. For example, SAMHSA annually collects information from states to determine their compliance with the Synar Amendment and its implementing regulation regarding the sale and distribution of tobacco products to minors. Similarly, DOJ is conducting a national evaluation of the Drug-Free Communities Support program to determine the effects the program is having on preventing and reducing unhealthy behaviors among youth, such as the use of tobacco, alcohol, or other drugs.

Federal departments coordinate their efforts to prevent and reduce tobacco use among youth by participating on various committees and work groups and collaborating on programs, research, and other activities-with HHS leading many of these efforts. HHS brings together representatives from federal, state, and local government agencies and nongovernmental entities to participate in various interagency committees and work groups that address tobacco prevention, cessation, and treatment of nicotine addiction. In addition, HHS and other federal departments share responsibility for administering programs, conducting and disseminating information on research, and engaging in education and outreach activities. Some HHS officials described challenges to coordination among HHS agencies. Several officials explained that, although multiple HHS agencies have programs and other efforts that aim to prevent and reduce tobacco use, coordination can be challenging because the missions and priorities of these agencies differ.

We provided a draft of this report to HHS, DOD, DOJ, and Education for comment. In written comments, HHS stated that the report provides a thorough and informative overview of the federal effort to prevent and reduce youth smoking. HHS noted that the report does not include the Centers for Medicare \& Medicaid Services programs that are a substantial element of HHS tobacco prevention, particularly Medicaid. Including joint federal-state programs that finance health insurance such Medicaid and the State Children's Health Insurance Program, was beyond the scope of our review. HHS also noted that the report does not include information about the challenges federal agencies other than HHS experienced in coordinating tobacco-related issues. Officials from DOD, DOJ, and Education did not provide information on challenges they experienced in coordinating their tobacco-related efforts. DOD concurred with the report as written and DOJ officials said they had no comments. HHS and Education provided technical clarifications which we made, as appropriate. 
From 1991 through 2002, smoking rates among youth fluctuated and reached their highest points around 1997. The estimated rate of current smoking among youth (defined as smoking one or more cigarettes during the previous 30 days) varied according to grade level ${ }^{8}$ (see fig.1). For example, the rate among 8th grade students peaked at about 21 percent in 1996 before declining to about 11 percent in 2002. For 10th grade students, the smoking rate peaked at 30 percent in 1996 before declining to 18 percent in 2002. Similarly, smoking among 12th grade students peaked at about 37 percent in 1997, before declining to about 27 percent in 2002.

Figure 1: Estimated Rate of Current Smoking among 8th, 10th, and 12th Grade Students, 1991-2002

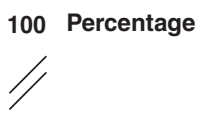

40

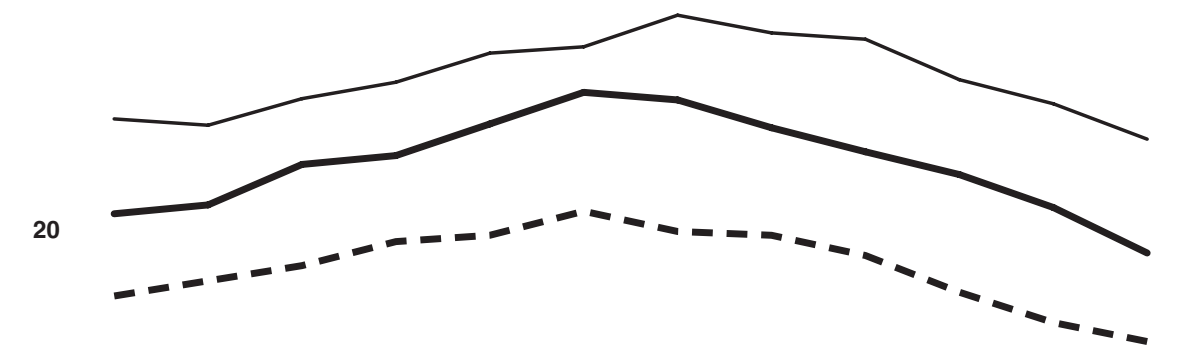

0

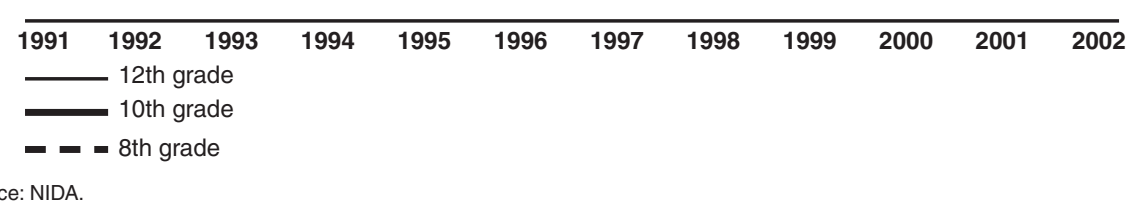

Note: Based on data from the Monitoring the Future survey, 2002.

HHS serves as the lead federal department for addressing the nation's public health issues, including tobacco use. HHS is responsible for informing the public of the dangers of tobacco use and coordinating

${ }^{8}$ L.D. Johnston, P.M. O'Malley, and J.G. Bachman, Monitoring the Future: National Results on Adolescent Drug Use: Overview of Key Findings, 2002, NIH Publication No. 03-5374 (Bethesda, Md.: National Institute on Drug Abuse, 2002). 
federal efforts to address tobacco use issues. Within HHS, CDC's Office on Smoking and Health has been delegated the lead for all policy and programmatic issues related to the prevention and reduction of tobacco use and has primary responsibility within the federal government for tobacco use prevention efforts. ${ }^{9}$ Also within HHS, the Surgeon General serves as the nation's spokesperson on matters of public health and reports on issues such as the health effects of tobacco use. Other HHS agencies, such as SAMHSA, NIH, and HRSA, support efforts to prevent and reduce tobacco use. Education, DOD, and DOJ also support programs and activities that aim to address tobacco use among youth.

Several studies have highlighted the importance of addressing tobacco use among youth. In 1994, the Surgeon General released a report that focused on the use of tobacco among youth. The report highlighted several factors that increase the likelihood that youth will begin using tobacco. These factors include engaging in other unhealthy behaviors, like substance abuse and violence; peer pressure to smoke; and cigarette advertising and promotion. In addition, the Surgeon General, CDC, NIH, and the Institute of Medicine have reported on approaches that can help prevent youth from starting to use tobacco and help existing users quit. For instance, they have reported on the demonstrated benefits of interventions such as implementing counter-marketing campaigns, using school-based educational programs in combination with providing youth with alternatives to the illicit use of tobacco, deglamorizing tobacco use, and restricting minors' access to tobacco. According to the Surgeon General's 1994 report, strategies for preventing and reducing tobacco use among youth should be multifaceted and involve collaborations among those that can influence the behavior and attitudes of youth, such as family members and educators.

HHS led federal, state, and local agencies and nongovernmental organizations in developing a 10-year national plan, the Healthy People 2010 initiative, that includes goals for addressing tobacco use. The Healthy People 2010 initiative has identified tobacco use as one of 10 leading health indicators for the nation. ${ }^{10}$ Healthy People 2010 objectives related to

\footnotetext{
${ }^{9}$ The Office on Smoking and Health is a division of the National Center for Chronic Disease Prevention and Health Promotion.

${ }^{10}$ The Healthy People 2010 leading health indicators are physical activity, overweight and obesity, tobacco use, substance abuse, responsible sexual behavior, mental health, injury and violence, environmental quality, immunization, and access to health care.
} 
tobacco use among youth include, among other objectives, reducing the percentage of adolescents who smoked cigarettes in the past month and increasing the percentage of adolescents who try to quit smoking.

Some Federal Programs, Research, and Activities Focus Only on Tobacco Use, While Others Address Tobacco Use Along with Other Unhealthy Behaviors
Two HHS agencies, CDC and SAMHSA, administer programs that focus only on tobacco use. CDC's NTCP targets youth within a broader mission of preventing and reducing tobacco use among the general population. SAMHSA oversees implementation of the Synar Amendment that requires states to enact and enforce tobacco control laws prohibiting the sale of tobacco products to minors. Other programs and activities administered by HHS, DOD, DOJ, Education, and the Office of National Drug Control Policy (ONDCP) address tobacco use as part of a broader focus on unhealthy behaviors, such as substance abuse and violence. (See app. II for examples of federal programs that can address tobacco prevention and reduction among youth.)

\section{Some Federal Programs Only Address Tobacco Use}

We identified two federal programs that focus only on tobacco use. The first, CDC's NTCP, ${ }^{11}$ focuses on preventing and reducing tobacco use among the general population, but it also explicitly targets tobacco use among youth. NTCP provides funds through cooperative agreements to all states. ${ }^{12}$ In fiscal year 2002, NTCP provided about $\$ 58$ million to states to address NTCP's four goals. ${ }^{13}$ NTCP's four goals are to (1) prevent youth from starting to smoke, (2) help youth and adults quit smoking, (3) minimize the public's exposure to secondhand smoke, and (4) identify and mitigate the factors that make some populations more likely to use tobacco than others. NTCP cooperative agreements specify the terms under which federal funds are provided to the states.

\footnotetext{
${ }^{11}$ In 1999, two HHS demonstration projects-the American Stop Smoking Intervention Study for Cancer Prevention and the Initiatives to Mobilize for the Prevention and Control of Tobacco Use-were combined to form NTCP.

${ }^{12}$ In our discussion of NTCP, the term "states" refers to the 50 states, the District of Columbia, and American Samoa, Guam, the Federated States of Micronesia, the Commonwealth of the Northern Mariana Islands, the Republic of Palau, Puerto Rico, and the U.S. Virgin Islands.

${ }^{13}$ In addition to NTCP funds, states use funds from other sources, such as other federal programs and initiatives, state taxes and state settlements with tobacco companies, and competitive grants from private foundations to finance their tobacco control programs and activities.
} 
Under NTCP, CDC encourages states to use multiple types of interventions in their efforts to prevent and reduce tobacco use. CDC has developed guidance intended to assist states in designing, implementing, and evaluating their individual tobacco control programs. ${ }^{14}$ For instance, CDC recommends that states establish comprehensive tobacco control programs that include certain components, such as

- community-based programs to reduce tobacco use that include a wide range of prevention activities, such as engaging youth in developing and implementing tobacco control interventions, conducting educational programs for young people, parents, school personnel, and others, and restricting access to tobacco products;

- school programs to implement school health policies that consist of tobacco-free policies, evidence-based curricula, teacher training, parental involvement, cessation services, and links between school and other community efforts and state media and educational campaigns;

- marketing campaigns to counter protobacco influences and increase prohealth messages and influences, including paid television, radio, billboard, and print media campaigns;

- cessation services to help people quit smoking;

- enforcement of tobacco control policies by restricting minors' access to tobacco and restricting smoking in public places; and

- statewide efforts to provide localities with technical assistance on how to evaluate tobacco programs, promote media advocacy, implement smokefree policies, and reduce minors' access to tobacco.

CDC officials told us that CDC also provides training and technical assistance to states in designing, implementing, and evaluating their tobacco control programs. For example, in fiscal year 2000, CDC conducted three regional workshops for state health departments and education agencies aimed at helping such agencies develop coordinated plans to prevent youth from starting to use tobacco. According to CDC, representatives from 33 states participated in these workshops.

The second federal program that focuses only on tobacco and aims to prevent tobacco use among youth is SAMHSA's program to oversee state implementation of legislation commonly referred to as the Synar Amendment. This program is the only one we identified that focuses solely on tobacco use among youth. The Synar Amendment and its implementing

\footnotetext{
${ }^{14}$ Centers for Disease Control and Prevention, Best Practices for Comprehensive Tobacco Control Programs, August 1999 (Atlanta Ga.: 1999).
} 
regulation require states to enact and enforce laws that prohibit the sale of tobacco products to minors, conduct random inspections of tobacco retail or distribution outlets and estimate the percentage of retailers that illegally sell tobacco to minors, and report the results of their efforts to the Secretary of HHS. ${ }^{15}$ States are also required to report enforcement actions taken against those who violate state laws in order to receive certain federal grants. ${ }^{16}$ By the end of fiscal year 2003, states may have no more than 20 percent of retail tobacco outlets in violation of state laws that prohibit the sale of tobacco products to minors. To oversee states' efforts to accomplish this, SAMHSA and the states negotiated interim annual target rates that states should meet. States may use a portion of their Substance Abuse Prevention and Treatment block grant to help fund the design and implementation of their inspection programs. For fiscal year 2002 , the states reported that they planned to expend more than $\$ 5.4$ million in block grant funds on Synar-related activities.

\section{Other Federal Programs Address Tobacco Use Along with Other Unhealthy Behaviors}

Other federal programs aim to address tobacco use among youth as part of a broader focus on unhealthy behaviors. For example, CDC's Coordinated School Health program provides grants to states to implement school health programs to prevent a range of unhealthy behaviors or conditions, such as drug, alcohol, and tobacco use; physical inactivity; poor nutrition, and obesity. In fiscal year 2002, CDC awarded grants to 22 states, with each state receiving approximately $\$ 400,000$. CDC helps state education and health departments identify and implement health education curricula to provide youth with information and the decision-making, communication, and peer-resistance skills needed to avoid unhealthy

\footnotetext{
${ }^{15} 42$ U.S.C. § 300x 26 (2002) Synar Amendment: 45 C.F.R. § 96.130 (2002) implementing regulation. SAMHSA requires states to develop and implement a consistent sample design and a standardized inspection procedure. SAMHSA provides guidance to states on effective ways to conduct unannounced inspections and to estimate statewide violation rates. See U.S. General Accounting Office, Synar Amendment Implementation: Quality of State Data on Reducing Youth Access to Tobacco Could Be Improved, GAO-02-74 (Washington, D.C.: Nov. 7, 2001).

${ }^{16} 42$ U.S.C. $\S 300 x-26(b)(2)(B)(i)$ (2000). States must comply with the Synar Amendment and its implementing regulation to obtain federal Substance Abuse Prevention and Treatment block grants. The Synar Amendment provides for a 40 percent reduction in a state's Substance Abuse Prevention and Treatment block grant for noncompliance with Synar requirements. However, provisions contained in the HHS annual appropriations acts since fiscal year 2000 have prohibited the Secretary of HHS from withholding grant funds from noncompliant states that pledge to commit state funds to ensure compliance with state laws prohibiting tobacco sales to minors. (See, e.g., Consolidated Appropriations Resolution, 2003, Pub. L. No. 108-7, Div. G, § 214, 117 Stat. 11, 324.)
} 
behaviors. In addition, CDC provides guidance to state and local health education agencies on tobacco prevention programs in schools that covers policies, programs, and a tobacco-free environment. CDC periodically surveys the states, school districts, and schools on the health curricula they offer and on school health policies relating to tobacco prevention and reduction efforts. According to $\mathrm{CDC}$, the information obtained through these survey efforts is used to assess trends in school health education programs.

Education's Safe and Drug-Free Schools and Communities program aims to prevent violence and drug, alcohol, and tobacco use in the nation's schools. ${ }^{17}$ Under this program in fiscal year 2002, Education awarded more than $\$ 472$ million in grants to state education departments and governors' offices. ${ }^{18}$ Similarly, the Safe Schools/Healthy Students program, which is funded by Education, HHS, and DOJ, provides local education agencies with grants that support a variety of services designed to promote healthy childhood development and prevent substance abuse (which can include the use of tobacco) and violence. These services target preschoolers, school-aged children, and adolescents. The Safe Schools/Healthy Students program's activities totaled about $\$ 172$ million for fiscal year 2002 .

DOJ and DOD support drug prevention programs that also aim to prevent tobacco use among youth. For example, the Drug-Free Communities Support program ${ }^{19}$ which is administered by ONDCP and DOJ, is designed to support the efforts of community coalitions that aim to prevent and reduce young people's use of drugs, alcohol, and tobacco. These coalitions consist of youth, parents, health care professionals, educators, law enforcement officials, and other community partners. In fiscal year 2002,

\footnotetext{
${ }^{17}$ This program was authorized under the Safe and Drug-Free Schools and Communities Act, Title IV, Part A of the Elementary and Secondary Education Act of 1965 as amended by the No Child Left Behind Act of 2001, Pub. L. No. 107-110, §401, 115 Stat.1425, 1734-1765 (classified to 20 U.S.C. § 7101-7165 (Supp. I 2002)). The program has two main components, a state grant program and a national program. The national program provides discretionary funding for demonstration projects, special initiatives, technical assistance to states and districts, evaluation, and other efforts to improve drug and violence prevention.

${ }^{18}$ These grants afford grantees significant discretion in implementing the federal program. In general, the Safe and Drug-Free Schools and Communities Act State Grants program funds a variety of violence, drug, alcohol, and tobacco prevention activities, including prevention instruction for students; and teacher and staff training and support services for students.

${ }^{19}$ This program was authorized by the Drug-Free Communities Act of 1997, Pub. L. No. 10520, § 2, 111 Stat. 224, 226 (classified to 21 U.S.C. $§ 1531(2000)$ ).
} 
DOJ awarded about $\$ 46$ million to community coalitions located in 50 states. Approximately $\$ 7$ million was given in new awards to 70 community coalitions, and $\$ 39$ million was given in renewed funding to 462 existing community coalitions. Another program, the Drug Education for Youth program (DEFY), which is sponsored by DOD and DOJ, targets youth aged 9 to 12 to improve awareness of the harmful effects of alcohol and other drugs, including tobacco. According to agency officials, the program aims to promote positive self-images and lifestyles. In fiscal year 2002, DOD funding totaled over $\$ 1$ million for 55 local DEFY programs. DOJ provided approximately $\$ 850,000$ in funding to implement 111 local DEFY programs.

HHS Agencies Support Research to Address Tobacco Use among Youth
In addition to supporting programs that aim to address tobacco use among youth, HHS agencies conduct research on tobacco use and its health effects. NIH's National Cancer Institute (NCI) has identified tobacco use among youth as one of its research priorities. ${ }^{20}$ In fiscal year 2002, NCI funded more than 40 grants, totaling almost $\$ 30$ million, for research on ways to understand, prevent, reduce, and treat tobacco use among youth. Similarly, NIH's National Institute on Drug Abuse (NIDA) supports research on effective tobacco use prevention and reduction interventions for youth. For example, NIDA established and funds a teen tobacco addiction treatment research center to examine methods of eliminating dependence on nicotine and assess the effectiveness of these strategies. The center is assessing the safe use and effectiveness of nicotine patches and gum for adolescents. According to NIDA, in fiscal year 2002, funding for its research projects that focused on substance abuse, including tobacco use among youth, totaled about $\$ 124$ million.

In fiscal year 1999, NCI and NIDA jointly established seven Transdisciplinary Tobacco Use Research Centers (TTURCs) at academic institutions in an effort to identify effective ways to prevent and reduce tobacco use. ${ }^{21}$ According to HHS officials, additional information on ways to reduce tobacco use among youth is needed because of the limited knowledge available about cessation interventions that work best for young people. The 5-year TTURCs research effort is designed to study new

\footnotetext{
${ }^{20}$ Other NIH institutes, such as the National Institute of Child Health and Human Development (NICHD) and the National Institute of Dental and Craniofacial Research (NIDCR) also conduct research on tobacco use among youth.

${ }^{21}$ The Robert Wood Johnson Foundation also provides funding for TTURCs.
} 
ways of preventing tobacco use and nicotine addiction. According to HHS officials, in fiscal year 2002, NCI and NIDA provided over $\$ 15$ million to TTURCs, which included funding for research on youth and adolescent tobacco use and nicotine addiction at four of the seven centers. These four centers are conducting studies on adolescent smoking. ${ }^{22}$ According to NCI, one study found that students with high academic performance, perceived academic competence, and involvement in school-related clubs and sports teams were less likely to smoke. ${ }^{23}$

CDC also supports research on health promotion and disease prevention including research on tobacco use among youth, through its network of 28 research centers that are affiliated with schools of public health, medicine, or osteopathy located throughout the country. According to CDC officials, these research centers focus on identifying effective prevention strategies that can be applied at the community level. One center is examining factors that can influence youth and young adults to start using tobacco and two other centers are conducting research that examines youth cessation programs, according to CDC. HRSA is working with certain federally supported community health centers on a multiyear initiative to address health disparities among youth. HRSA officials said that the effort would involve developing interventions to address the needs of high-risk medical subpopulations, such as young people with asthma or cardiovascular conditions for whom tobacco use can pose especially high risks.

Federal Activities Also Aim to Address Tobacco Use among Youth
In addition to research, HHS and other federal departments conduct a variety of tobacco-focused activities that aim to prevent and reduce tobacco use among youth. For example, officials from HHS, Education, and other federal departments, along with experts from national organizations and professional associations, developed guidance to help schools identify and implement strategies for preventing tobacco use

\footnotetext{
${ }^{22}$ These four centers are located at Brown University, the University of Pennsylvania/Georgetown University, the University of Southern California, and the University of California at Irvine. The other funded research centers are located at the University of Minnesota, University of Wisconsin Medical School, and Yale University.

${ }^{23}$ The Nation's Investment in Cancer Research for Fiscal Year 2003, National Cancer Institute, National Institutes of Health (http:/plan2003.cancer.gov/scipri/tobacco.htm).
} 
among youth. ${ }^{24}$ For example, the guidelines recommend that schools develop and enforce a school policy on tobacco use, provide tobacco-use prevention education from kindergarten through 12th grade, provide instructions about the short- and long-term consequences of tobacco use, and provide training for teachers. Similarly, in 1997, SAMHSA issued guidance that describes strategies that communities can use to prevent and reduce tobacco use among youth. ${ }^{25}$

In other activities, HHS agencies develop and promote educational materials to prevent and reduce a range of unhealthy behaviors among adolescents, including tobacco use. For example, Girl Power!, a national public education campaign, is designed to prevent 9- to 13-year-old girls from using tobacco, alcohol, and illegal drugs and includes a Web site that offers articles, games, and quizzes that teach girls about the dangers of tobacco use. Similarly, CDC's Tobacco Information and Prevention Source Web site offers a variety of educational materials for youth, such as tips on how to quit using tobacco and information on the health consequences of using tobacco. CDC also disseminates information for parents, such as a kit that offers advice on ways to increase parental involvement in their children's lives and incorporate tobacco prevention messages into daily activities. In addition, DOD sponsors Web sites that include information on preventing and reducing tobacco use among youth and supports various youth activities that address unhealthy behaviors, including tobacco use. For example, one project identified was Smart Moves, ${ }^{26}$ which aims to prevent tobacco, alcohol, and drug use by bolstering youths' self-esteem and their resistance to unhealthy behaviors.

HHS agencies also support activities that use various media, such as print, radio, television, and videotapes, to counteract the impact of tobacco product marketing. For example, CDC supports a variety of entertainmentrelated outreach activities that enlist celebrities as spokespersons to deliver antismoking messages and to increase prohealth messages in

\footnotetext{
${ }^{24}$ Centers for Disease Control and Prevention, Guidelines for School Health Programs to Prevent Tobacco Use and Addiction, Morbidity and Mortality Weekly Report, vol. 43, no. RR-2, 1-18 1994 (Atlanta, Ga.: 1994), 43.

${ }^{25}$ U.S. Department of Health and Human Services, Reducing Tobacco Use Among Youth: Community-Based Approaches, Prevention Enhancement Protocol, 1997, DHHS Publication No. 97-3146 (Rockville, Md., Substance Abuse and Mental Health Administration: 1997).

${ }^{26}$ This program was developed by the Boys and Girls Club of America.
} 
entertainment programming. CDC also supports the Media Campaign Resource Center, a clearinghouse offering antitobacco media products developed for television, radio, print, and outdoor advertising. In addition, CDC and SAMHSA developed Media Sharp, a media literacy guide for educators and community leaders who work with middle school and high school age youth to dissuade youth from using tobacco.

\section{Federal Departments and Agencies Collect a Variety of Information on Their Programs That Aim to Prevent Tobacco Use among Youth}

To monitor federal programs that aim to prevent and reduce tobacco use among youth, federal departments and agencies collect information on how their programs are being implemented by grantees and the effectiveness of grantees' efforts in meeting national program goals. Federal departments and agencies obtain this information from various sources, such as grantee applications for federal funding, progress reports, site visits, and program evaluations. According to federal officials, the information is used to assist grantees in managing and evaluating their programs.

\section{CDC Collects Information on the States' NTCP- Supported Tobacco Control Programs}

To monitor the NTCP, CDC collects information on the design, implementation, and effectiveness of state tobacco control programs. CDC obtains this information through various sources, such as states' applications for NTCP funding, state progress reports, periodic site visits, surveys, and program evaluations conducted by various states. For instance, the applications that states submit when applying for NTCP funding must include strategic plans that provide information on the design and implementation of their tobacco control programs. The plans must also include information on how states will achieve NTCP's goals. According to CDC officials, other important sources of information are the biannual reports that the agency requires states to submit on the progress of their tobacco control programs. These reports provide CDC with additional information, such as enforcement strategies used to prevent the sale of tobacco products to minors, information campaigns to increase the public's awareness of the health consequences of using tobacco, and efforts to promote tobacco-free schools and positive role models for youth. 
CDC also obtains information on state tobacco control programs through other sources. For example, CDC officials said that NTCP project officers, who are responsible for monitoring state tobacco control programs, visit each of their assigned states approximately every 12 to 18 months. CDC officials said that through these visits they obtain more in-depth information about the design and implementation of the states' programs, and they gain a better understanding of the challenges that states may face in achieving NTCP's goals. In addition, these officials said that they monitor the effects of state tobacco control programs through periodic national and state youth tobacco surveys. Through these surveys, CDC obtains information on changes in tobacco use among youth and their knowledge, attitudes, and behaviors towards tobacco use. CDC officials said that they work with the states to design the state surveys and to help states interpret and use the survey data. CDC officials also said that they have obtained useful information from evaluations that several states completed on the effectiveness of their tobacco control programs. ${ }^{27}$

According to CDC officials, the information they obtain has been used in various ways. For example, in developing its best practice guidance for comprehensive tobacco control programs, CDC used information from analyses of tobacco control programs in California and Massachusetts and CDC officials' experience in providing technical assistance in other states. CDC officials also said that the agency has provided a variety of training and technical assistance to help states, among other things, adopt evidence-based interventions for preventing tobacco use. In addition, CDC developed guidance in 2001 on how states could evaluate their individual tobacco control programs. ${ }^{28}$ The guidance includes information on approaches for designing evaluations; measuring outcomes of specific program components; and analyzing, interpreting, and using evaluation results to improve operations and enhance the impact of tobacco control programs.

\footnotetext{
${ }^{27}$ According to CDC officials, evaluations of state tobacco control programs have been completed by Arizona, California, Florida, Maine, Massachusetts, Mississippi, Oregon, and Texas.

${ }^{28}$ Goldie MacDonald and others, Introduction to Program Evaluation for Comprehensive Tobacco Control Programs (Atlanta, Ga.: Centers for Disease Control and Prevention, November 2001) and Centers for Disease Control and Prevention, Surveillance and Evaluation Data Sources for Comprehensive Tobacco Control Programs (Atlanta, Ga.: November 2001).
} 
In fiscal year 2003, CDC took action to collect additional information on the design, implementation, and effectiveness of state tobacco control programs. For instance, CDC now requires that states submit additional information in their biannual reports. These officials said that the expanded NTCP data collection effort should enable CDC to obtain a more comprehensive picture of state tobacco control programs and the extent to which program activities are consistent with NTCP's goals. CDC officials said that they anticipate that these changes, along with the redesign of the NTCP information system, will facilitate more comprehensive comparisons within and across states and regions on progress towards reducing tobacco use. The changes should also enable CDC to better identify state-specific or systemic issues, according to these officials.

In fiscal year 2003, CDC began requiring that each state dedicate staff to evaluate the state's tobacco control program. Each state was required to submit detailed information with its NTCP funding application that described how it intended to evaluate the program's effectiveness. The application had to include information on the specific performance indicators the state intends to use and its methodologies for collecting and analyzing data, projected time lines for completing evaluation efforts, and plans for using evaluation results to improve its program. CDC officials told us that they recognize that conducting program evaluations can present financial and methodological challenges for state tobacco control programs, but that CDC had instituted this requirement because evidence on the impact of individual state programs has been generally limited. These officials noted that while evaluations have been completed by eight states, the results of these evaluations and other studies provide only a limited picture of the impact of all states' programs in achieving NTCP's goals.

SAMHSA Collects
Information on States'
Progress in Prohibiting the
Sale of Tobacco Products
to Minors

To monitor state compliance with the requirements of the Synar Amendment and its implementing regulation, SAMHSA collects data on the design and implementation of state compliance efforts. The regulation requires that each state report to SAMHSA information on the state's efforts to inspect retail tobacco outlets, including the state's sampling methodology, inspection protocol, and inspection results. SAMSHA reviews the information to determine whether states have complied with requirements for enforcing state laws and conducting random inspections of retail tobacco outlets. In reviewing these data, SAMHSA determines whether a state's estimated retailer violation rate meets negotiated annual targets and shows progress toward the 20 percent goal. Based on the latest 
data available at the time of our review, 49 states met their negotiated retailer violation rate targets for 2002 .

Federal Departments and Agencies Collect Information on Their Programs That Address Unhealthy Behaviors among Youth
Federal agencies with programs that address tobacco use, along with other unhealthy behaviors among youth, obtain information on grantees' efforts to design and implement their programs. They obtain this information by various means, such as periodic reports and visits to grantee sites. For example, DOJ requires community antidrug coalitions that participate in the Drug-Free Communities Support program to submit annual progress reports on their programs. As part of this reporting requirement, coalitions must report on certain measures of youth behavior, such as the age youth first started to use tobacco, the frequency of tobacco use in the past 30 days, and youths' perceptions of tobaccorelated risks. According to DOJ officials, the information obtained from reports and site visits is used to provide grantees with training and technical assistance. DOJ is also overseeing a 5-year evaluation of the effectiveness of this federal grant program. The evaluation, which is scheduled for completion in 2004, is designed to take into consideration both the similarities and differences among the coalitions and their communities and aims to assess the effectiveness of the coalitions' efforts to reduce the use of tobacco, alcohol, and illicit drugs among youth.

Similarly, to monitor their programs, DOJ and DOD contracted for evaluations of the effectiveness of some DEFY components. For instance, one study examined the effectiveness of the summer camp component in 1997 at 18 DOJ DEFY camps and 28 military DEFY camps. The study included the use of pre- and postcamp questionnaires to assess youths' attitudes towards smoking cigarettes and to determine how often they smoked..$^{29}$

\footnotetext{
${ }^{29}$ We did not review the methodology used in the evaluation of DEFY.
} 
Federal Departments and Agencies Coordinate in Various Ways to Address Tobacco Use among Youth
HHS and other federal departments coordinate their efforts to prevent, treat, and reduce tobacco use among youth by participating on various committees and work groups and by collaborating on various programs, research projects, and activities. Although HHS has the lead responsibility for coordinating these efforts, some HHS officials stated that coordination among HHS agencies presents challenges.

\author{
HHS Leads Coordination \\ Efforts to Address \\ Tobacco Use
}

HHS leads efforts among its agencies and others to develop strategies for addressing tobacco use among youth in support of the Healthy People initiative, which includes objectives to reduce tobacco use among youth. As part of this initiative, representatives from various federal departments and nongovernmental organizations participate in work groups that focus on tobacco use objectives. For example, the Healthy People 2010 Tobacco Use Work Group, chaired by CDC, includes representatives from other HHS agencies as well as the Environmental Protection Agency (EPA), the Federal Trade Commission, and nonfederal organizations. The work group meets periodically to discuss strategies and challenges in addressing issues related to tobacco use. ${ }^{30}$

HHS also plays a leadership role in the Youth Tobacco Cessation Collaborative. Established in 1998, the collaborative brings together CDC, NCI, NICHD, NIDA, the National Heart, Lung, and Blood Institute (NHLBI), and several nonfederal organizations to help ensure young tobacco users' access to cessation interventions. ${ }^{31}$ In 2000 , the collaborative published an action plan to facilitate planning and priority-setting on the need for tobacco cessation for youth. ${ }^{32}$ In addition, three members of the

\footnotetext{
${ }^{30}$ Other HHS agencies represented on the Tobacco Use Work Group are the Administration for Children and Families, the Agency for Healthcare Research and Quality (AHRQ), the Centers for Medicare \& Medicaid Services (CMS), HRSA, the Indian Health Service (IHS), NIH, and SAMHSA.

${ }^{31}$ Nonfederal members involved in the collaborative include the American Cancer Society, the American Legacy Foundation, the American Lung Association, the Canadian Tobacco Research Initiative, the National Cancer Institute of Canada, and the Robert Wood Johnson Foundation.

${ }^{32}$ Center for the Advancement of Health for the Youth Tobacco Cessation Collaborative, National Blueprint for Action: Youth and Young Adult Tobacco-Use Cessation (Washington, D.C.: 2000).
} 
collaborative-CDC, NCI, and the Robert Wood Johnson Foundation-are working together on the Helping Young Smokers Quit initiative, a 4-year project that aims to identify, characterize, and evaluate the effectiveness of various youth cessation programs.

Other work groups focus on broader adolescent health issues that include tobacco use among youth. For example, both the Healthy People 2010 Adolescent Health Work Group, cochaired by CDC and HRSA, and the related National Initiative to Improve Adolescent Health by 2010 aim to foster greater involvement by various professions to improve the overall health of adolescents, in part by reducing their use of tobacco. According to HRSA officials, members of the national initiative are trying to educate health care and other professionals on the importance of screening for tobacco use and other unhealthy behaviors during routine health care visits, providing counseling on the benefits of quitting tobacco use, and providing referrals for youth, their parents, and other family members to tobacco cessation services. As part of the national initiative, CDC, HRSA, and the American Academy of Pediatrics are collaborating on the development of a prevention guide to help pediatricians address unhealthy behaviors among youth, including tobacco use.

\section{HHS Established the Interagency Committee on Smoking and Health to Coordinate Federal Efforts}

In 1984, the Congress passed legislation requiring, among other things, that HHS establish an interagency committee to coordinate the department's research, educational programs, and other smoking and health efforts with similar efforts of other federal departments and nonfederal organizations. ${ }^{33}$ As a result, in 1985, HHS established the Interagency Committee on Smoking and Health. According to CDC officials, the committee brings together representatives of federal agencies and nonfederal organizations involved in tobacco use issues ${ }^{34}$ and serves as a forum for committee members and the public to share information and discuss a variety of tobacco-related issues and efforts. Committee meetings that have specifically focused on tobacco use among youth have covered such

\footnotetext{
${ }^{33}$ Comprehensive Smoking Education Act of 1984, Pub. L. No. 98-474 § 3, 98 Stat. 2200-2201 (classified to 15 U.S.C. $\$ 1341(b)(2000)$ ).

${ }^{34}$ As of October 2003, other federal entities represented on the Interagency Committee on Smoking and Health are HHS's AHRQ, CDC, CMS, HRSA, IHS, NCI, NICHD, NIDA, NHLBI, and SAMHSA; the Departments of Labor and Transportation; EPA; and the Federal Trade Commission.
} 
topics as the health effects of smoking on young people, the sale of cigarettes to minors, and strategies for preventing tobacco use.

HHS and Other Federal Departments Coordinate Their Efforts by Jointly Administering Programs and Supporting Research and Activities
Federal departments also collaborate on efforts to prevent and reduce tobacco use among youth by jointly administering programs, conducting research, and supporting education and outreach activities. For example, Education, DOJ, and HHS jointly administer the Safe Schools/Healthy Students program. Through interagency agreements, Education handles grants management activities, HHS provides technical advice and financial assistance, and DOJ oversees program evaluation efforts. Similarly, for the Drug-Free Communities Support program, ONDCP directs the program and through an interagency agreement transfers funds to DOJ to cover grant awards, grants management, and evaluation activities. Both ONDCP and DOJ provide technical assistance to program grantees.

HHS agencies also coordinate on efforts to jointly support research on tobacco use prevention and cessation. For example, in addition to the NCIand NIDA-supported TTURCs initiative, NCI led the creation of an NIHwide Tobacco and Nicotine Research Interest Group in January 2003. According to NCI officials, the group was established to leverage expertise and resources across NIH for tobacco research. In addition to NCI, representatives from other NIH institutes, such as NICHD, NIDA, NHLBI, and the National Institute of Dental and Craniofacial Research (NIDCR) have participated in the group. Representatives from CDC are also participating in the group's meetings.

Furthermore, HHS agencies, Education, ONDCP, and nonfederal organizations collaborate on education and outreach activities aimed at discouraging youth from starting to use tobacco and encouraging existing users to quit. For example, CDC and Education collaborated on the development and dissemination of a guide for parents on how to address their children's health needs, including preventing and reducing tobacco use. Table 1 highlights various education and outreach activities aimed at preventing and reducing tobacco use among youth that HHS and other federal departments and agencies work on together. 
Table 1: Examples of Federal Collaborative Education and Outreach Activities to Address Tobacco Use among Youth

\begin{tabular}{|c|c|c|}
\hline $\begin{array}{l}\text { Activity or } \\
\text { project }\end{array}$ & $\begin{array}{l}\text { Federal } \\
\text { departments } \\
\text { or agencies }\end{array}$ & Description \\
\hline $\begin{array}{l}\text { Tobacco-Free } \\
\text { Sports }\end{array}$ & $\begin{array}{l}\text { CDC, } \mathrm{NCl} \text {, } \\
\text { SAMHSA, and } \\
\text { ONDCP }\end{array}$ & $\begin{array}{l}\text { An initiative that involves sports stars, sport leagues, } \\
\text { and youth organizations helping to deliver tobacco- } \\
\text { free messages. The initiative is intended to depict } \\
\text { positive role models and provide information about } \\
\text { how to make positive health choices related to } \\
\text { tobacco use, physical activity, and nutrition. }\end{array}$ \\
\hline $\begin{array}{l}\text { Entertainment } \\
\text { Industry } \\
\text { Outreach }\end{array}$ & $\begin{array}{l}\text { CDC, NIDA } \\
\text { SAMHSA, and } \\
\text { ONDCP }\end{array}$ & $\begin{array}{l}\text { A multifaceted outreach effort to, among other things, } \\
\text { enlist celebrities to serve as national spokespersons } \\
\text { to deliver antismoking messages and to educate } \\
\text { young people on how to interpret depictions of } \\
\text { tobacco use in entertainment media. As part of this } \\
\text { effort, federal agencies have collaborated on } \\
\text { promoting a video-based media literacy program, } \\
\text { Scene Smoking: Cigarettes, Cinema, and the Myth of } \\
\text { Cool, aimed at high school and college students. }\end{array}$ \\
\hline $\begin{array}{l}\text { Pathways to } \\
\text { Freedom }\end{array}$ & $\mathrm{CDC}$ and $\mathrm{NCl}$ & $\begin{array}{l}\text { A self-help guide intended to motivate and assist } \\
\text { African American adults and youth to stop smoking. } \\
\text { The guide is intended to prevent young children from } \\
\text { developing the smoking behaviors of their parents } \\
\text { who use tobacco and to prevent exposure to } \\
\text { secondhand smoke. }\end{array}$ \\
\hline $\begin{array}{l}\text { Got a Minute? } \\
\text { Give It to Your } \\
\text { Kids }\end{array}$ & $\begin{array}{l}\text { CDC, } \\
\text { SAMHSA, } \\
\text { Education, } \\
\text { and ONDCP }\end{array}$ & $\begin{array}{l}\text { A guide to educate parents on how to } \\
\text { comprehensively address their children's health } \\
\text { needs, including information on how to prevent their } \\
\text { children from using tobacco. Education is assisting } \\
\text { CDC in disseminating the guide to schools } \\
\text { nationwide. }\end{array}$ \\
\hline
\end{tabular}

Source: HHS agencies, Education, and ONDCP. 
HHS Officials Identified Several Challenges to Coordination within the Department
HHS officials said that coordinating on tobacco-related issues within HHS presents challenges. They pointed out that, although multiple HHS agencies have programs and other efforts to address the prevention and reduction of tobacco use, the missions and funding priorities of the agencies differ. For example, CDC officials told us that they had initiated discussions in fiscal year 2003 with HRSA to collaborate on offering tobacco prevention and cessation services to underserved populations that obtain health care through HRSA's network of community health centers. However, this effort has been delayed largely due to HRSA's competing funding priorities and limited resources. In another instance, NCI officials noted that NIDA and NIDCR decided to fund a proposal to translate research findings on alcohol, tobacco, and other drug prevention and treatment research to clinical dental practice settings. However, according to an NCI official, NCI did not learn about the proposal in time to consider it for fiscal year 2003 funding.
Agency Comments comment. DOD concurred with the report as written and DOJ did not have comments. HHS and Education provided technical comments that we incorporated as appropriate.

In written comments, HHS stated that the report was very informative and provided a thorough overview of nicotine and tobacco activities related to youth, but did not include programs within CMS that are a substantial element of HHS tobacco prevention. Specifically, HHS stated that under Medicaid, states are required to cover certain smoking cessation services for children and adolescents. Including joint federal-state programs that finance health insurance such Medicaid and the State Children's Health Insurance Program, was beyond the scope of our review. HHS also noted that the report did not include information about the challenges other federal agencies experienced in coordinating tobacco-related issues. We discussed coordination of tobacco-related issues with officials from DOD, DOJ, and Education. However, these officials did not cite any challenges they had experienced with coordinating their tobacco-related efforts. 
As agreed with your office, unless you release its contents earlier, we plan no further distribution of this report until 30 days after the issue date. At that time, we will send copies of this report to the Secretary of Health and Human Services, the Secretary of Defense, the Attorney General, the Secretary of Education, appropriate congressional committees, and other interested parties. We will also make copies available to others upon request. In addition, the report is available at no charge on the GAO Web site at http://www.gao.gov. If you or your staff have questions about this report, please contact me at (202) 512-7101. An additional contact and staff acknowledgments are provided in appendix III.

Sincerely yours,

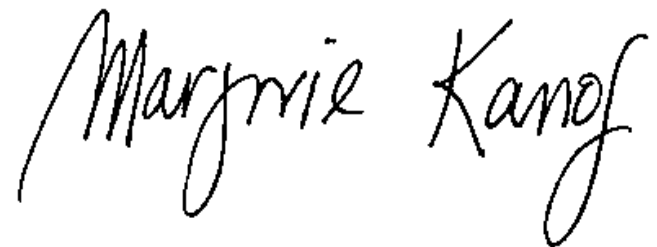

Marjorie E. Kanof

Director, Health Care-Clinical Health Care Issues 


\section{Appendix I: Scope and Methodology}

To do our work, we obtained and reviewed program documents, strategic and performance plans, pertinent program reports and special studies, surveillance and other data, and federal Web sites from the Department of Health and Human Services (HHS) including the Office of the Secretary, the Office of the Assistant Secretary for Planning and Evaluation, Office of Public Health and Science, Agency for Healthcare Research and Quality, Centers for Disease Control and Prevention (CDC), Centers for Medicare \& Medicaid Services, Health Resources and Services Administration (HRSA), Indian Health Service, National Institutes of Health (NIH), and Substance Abuse and Mental Health Services Administration (SAMHSA); the Departments of Defense (DOD), Justice (DOJ), and Education; the Environmental Protection Agency; the Federal Trade Commission; and the Office of National Drug Control Policy (ONDCP). We also reviewed the relevant literature and documents prepared by federal interagency committees and work groups that focused on the prevention and reduction of tobacco use among youth and adults.

To identify federal programs that aim to prevent and reduce tobacco use among youth (defined as children and adolescents under age 18), we reviewed the Catalog of Federal Domestic Assistance, a database of federal grant programs. ${ }^{1}$ We also reviewed pertinent documents and federal Web sites. After identifying federal programs, we interviewed and collected information from federal program officials to confirm that these programs supported efforts to prevent and reduce tobacco use among youth. ${ }^{2}$ As a result, we focused on four federal departments: HHS and its component agencies-CDC, SAMHSA, NIH, and HRSA; Education; DOJ; and DOD. We then obtained more detailed information on the programs they fund. We interviewed officials in HHS, DOD, DOJ, and Education and obtained information on program characteristics, including the purpose, target audience, and program and financial requirements. We also obtained information on research and activities that involve federal departments and agencies, such as education and outreach efforts intended to prevent the initiation of tobacco use among youth and help youth quit tobacco use. In conducting this work, we also reviewed strategic and annual performance plans, along with budgetary and other pertinent documents, including national action plans and tobacco use prevention and cessation guidance. Where available, we obtained fiscal

\footnotetext{
${ }^{1}$ The General Services Administration maintains this database.

${ }^{2}$ The scope of our work did not include programs that finance health insurance such as Medicaid.
} 
year 2002 funding information on the federal programs and research that we identified. However, we were unable to determine the extent of spending by federal agencies on efforts to prevent and reduce tobacco use among youth because, in many instances, funding information covers more than the prevention and reduction of tobacco use among youth. The programs, research, and activities that we discuss in this report do not represent an exhaustive list of all federal efforts to prevent and reduce tobacco use among youth, but highlight a range of such efforts.

To determine how federal departments and agencies monitor programs that aim to prevent and reduce tobacco use among youth and the types of monitoring information that departments and agencies collect, we obtained and reviewed descriptive information on federal departments and agencies' monitoring efforts. Specifically, we reviewed strategic plans, annual performance plans and reports, performance monitoring reports, program evaluation guidance, and copies of federal and state program evaluation reports. We also interviewed program officials to obtain a more detailed understanding of their monitoring efforts.

To determine how federal departments and agencies coordinate their efforts to address youth tobacco use, we focused our attention on identifying the key coordination mechanisms and the results of such coordination. Specifically, we reviewed strategic and annual performance plans and reports, interagency agreements, memorandums of understanding, minutes of interagency meetings, and other pertinent documents. We also interviewed federal program officials and obtained information from these officials describing the characteristics of various federal efforts, including information on purpose, federal agencies involved, and the target audience. We also obtained their perspectives on any factors presenting coordination challenges related to addressing youth tobacco use.

We conducted our work from January 2003 through October 2003 in accordance with generally accepted government auditing standards. Our findings are limited to the select examples identified and thus do not necessarily reflect the full scope of federal programs and other activities related to preventing and reducing tobacco use among youth. We did not assess the effectiveness of federal programs, monitoring efforts, or coordination activities. 


\section{Appendix II: Selected Federal Programs That Address or Can Address Tobacco Prevention and Reduction among Youth}

Table 2 lists selected federal grant programs that may be used to address tobacco use among youth. The list includes programs from four departments.

Table 2: Selected Federal Programs That Address or Can Address Tobacco Prevention and Reduction among Youth

\begin{tabular}{|c|c|c|c|c|}
\hline Program & $\begin{array}{r}\text { Funding fiscal } \\
{\text { year } 2002^{\mathrm{a}}}\end{array}$ & Eligible applicants $^{b}$ & $\begin{array}{l}\text { Targeted } \\
\text { beneficiaries }\end{array}$ & $\begin{array}{l}\text { Grant program } \\
\text { description }\end{array}$ \\
\hline \multicolumn{5}{|c|}{ Department of Health and Human Services } \\
\hline \multicolumn{5}{|c|}{ Centers for Disease Control and Prevention } \\
\hline National Tobacco Control & $\$ 58,000,000$ & States & General population & $\begin{array}{l}\text { To support state } \\
\text { tobacco control } \\
\text { programs to prevent } \\
\text { and reduce tobacco } \\
\text { use, including } \\
\text { preventing youth from } \\
\text { starting to smoke. }\end{array}$ \\
\hline Tribal Support Centers & $\$ 1,600,000$ & $\begin{array}{l}\text { Tribes and tribal } \\
\text { organizations }\end{array}$ & $\begin{array}{l}\text { American } \\
\text { Indian/Alaskan } \\
\text { Natives }\end{array}$ & $\begin{array}{l}\text { To support seven } \\
\text { tribal centers in } \\
\text { developing tobacco } \\
\text { control programs to } \\
\text { prevent and reduce } \\
\text { tobacco use, including } \\
\text { preventing youth from } \\
\text { starting to smoke. }\end{array}$ \\
\hline Coordinated School Health & $\$ 11,000,000$ & $\begin{array}{l}\text { State and local education } \\
\text { agencies }\end{array}$ & $\begin{array}{l}\text { Students in grades } 9 \\
\text { through } 12\end{array}$ & $\begin{array}{l}\text { To support school } \\
\text { health programs in } \\
\text { discouraging } \\
\text { unhealthy behaviors, } \\
\text { such as poor eating } \\
\text { habits, physical } \\
\text { inactivity, and tobacco } \\
\text { use. }\end{array}$ \\
\hline $\begin{array}{l}\text { Preventive Services Block Grant } \\
\text { to States }\end{array}$ & $\$ 408,450^{\circ}$ & States & General population & $\begin{array}{l}\text { To carry out public } \\
\text { health activities, } \\
\text { including preventing } \\
\text { tobacco sales to } \\
\text { minors. }\end{array}$ \\
\hline \multicolumn{5}{|c|}{ Health Resources and Services Administration } \\
\hline $\begin{array}{l}\text { Healthy Schools, } \\
\text { Healthy Communities }\end{array}$ & $\$ 19,500,000$ & $\begin{array}{l}\text { Public and nonprofit } \\
\text { private entities, including } \\
\text { faith-based and } \\
\text { community-based } \\
\text { organizations }\end{array}$ & $\begin{array}{l}\text { Students attending } \\
\text { schools (kindergarten } \\
\text { through grade 12) that } \\
\text { serve low-income or } \\
\text { high-risk children }\end{array}$ & $\begin{array}{l}\text { To increase access to } \\
\text { comprehensive } \\
\text { primary and } \\
\text { preventive health care } \\
\text { for underserved } \\
\text { children, adolescents, } \\
\text { and their families, } \\
\text { including tobacco } \\
\text { prevention and } \\
\text { reduction programs. }\end{array}$ \\
\hline
\end{tabular}




\begin{tabular}{|c|c|c|c|c|}
\hline Program & $\begin{array}{r}\text { Funding fiscal } \\
{\text { year } 2002^{\mathrm{a}}}\end{array}$ & Eligible applicants $^{b}$ & $\begin{array}{l}\text { Targeted } \\
\text { beneficiaries }\end{array}$ & $\begin{array}{l}\text { Grant program } \\
\text { description }\end{array}$ \\
\hline Community Health Centers & $\$ 1,077,578,000$ & $\begin{array}{l}\text { Public and nonprofit } \\
\text { private entities, including } \\
\text { faith-based and } \\
\text { community-based } \\
\text { organizations }\end{array}$ & $\begin{array}{l}\text { People in medically } \\
\text { underserved areas }\end{array}$ & $\begin{array}{l}\text { To develop and } \\
\text { operate community } \\
\text { health centers that } \\
\text { provide preventive and } \\
\text { primary health care } \\
\text { services, and link } \\
\text { clients with Medicaid } \\
\text { and mental health and } \\
\text { substance abuse } \\
\text { treatment, including } \\
\text { that for tobacco use. }\end{array}$ \\
\hline $\begin{array}{l}\text { Maternal and Child Health } \\
\text { Services Block Grant to States }\end{array}$ & $\$ 595,727,279$ & States & $\begin{array}{l}\text { Pregnant women, } \\
\text { mothers, infants and } \\
\text { children, and children } \\
\text { with special health } \\
\text { care needs, } \\
\text { particularly those of } \\
\text { low-income families }\end{array}$ & $\begin{array}{l}\text { To maintain and } \\
\text { strengthen state } \\
\text { leadership in planning, } \\
\text { promoting, } \\
\text { coordinating, and } \\
\text { evaluating health care } \\
\text { services. Funds can } \\
\text { be used for tobacco } \\
\text { prevention programs } \\
\text { and activities. }\end{array}$ \\
\hline
\end{tabular}

Substance Abuse and Mental Health Services Administration

Synar Amendment $\$ 5,448,273^{d}$ States

Children under age 18 To enable states to implement the Synar survey requirements to assess state compliance and enforcement of tobacco access control laws that prohibit the sale and distribution of tobacco products to individuals under age 18.

\begin{tabular}{|c|c|c|c|}
\hline $\begin{array}{l}\text { Substance Abuse Prevention and } \\
\text { Treatment Block Grant }\end{array}$ & $\$ 1,725,000,000$ States & General population & $\begin{array}{l}\text { To provide financial } \\
\text { assistance to states } \\
\text { for the purpose of } \\
\text { planning, carrying out, } \\
\text { and evaluating } \\
\text { activities to prevent } \\
\text { and treat substance } \\
\text { abuse, including youth } \\
\text { tobacco use. }\end{array}$ \\
\hline State Incentive Grants & $\$ 58,480,885$ States & Adolescents & $\begin{array}{l}\text { To prevent and reduce } \\
\text { alcohol, tobacco, and } \\
\text { illicit drug use by } \\
\text { adolescents ages } \\
12-17 \text {. }\end{array}$ \\
\hline
\end{tabular}




\begin{tabular}{|c|c|c|c|c|}
\hline Program & $\begin{array}{r}\text { Funding fiscal } \\
\text { year } 2002^{\mathrm{a}}\end{array}$ & Eligible applicants $^{b}$ & $\begin{array}{l}\text { Targeted } \\
\text { beneficiaries }\end{array}$ & $\begin{array}{l}\text { Grant program } \\
\text { description }\end{array}$ \\
\hline \multicolumn{5}{|l|}{ Department of Education } \\
\hline \multicolumn{5}{|c|}{ Office of Elementary and Secondary Education } \\
\hline $\begin{array}{l}\text { Safe and Drug-Free Schools and } \\
\text { Communities: State Grants }\end{array}$ & $\$ 472,017,000$ & $\begin{array}{l}\text { State departments } \\
\text { of education }\end{array}$ & $\begin{array}{l}\text { Children and youth } \\
\text { who are enrolled and } \\
\text { attending school } \\
\text { (primarily kindergarten } \\
\text { through grade 12) }\end{array}$ & $\begin{array}{l}\text { To support programs } \\
\text { that seek to prevent } \\
\text { violence in and around } \\
\text { schools; prevent illegal } \\
\text { use of alcohol, } \\
\text { tobacco, and drugs; } \\
\text { and coordinate with } \\
\text { federal, state, school, } \\
\text { and community efforts } \\
\text { to foster a safe and } \\
\text { drug-free learning } \\
\text { environment. }\end{array}$ \\
\hline & & Governors & $\begin{array}{l}\text { Children and youth not } \\
\text { normally served by } \\
\text { state or local } \\
\text { educational agencies, } \\
\text { or populations that } \\
\text { need special services } \\
\text { or additional resources } \\
\text { (for example, youth in } \\
\text { detention facilities and } \\
\text { runaway and } \\
\text { homeless youth) }\end{array}$ & $\begin{array}{l}\text { To support programs } \\
\text { of drug use (including } \\
\text { tobacco) and violence } \\
\text { prevention. }\end{array}$ \\
\hline
\end{tabular}

\section{Multiagency programs}

Drug-Free Communities Support

(DOJ and ONDCP)

$\$ 46,000,000$ Community coalitions Youth

To support coalitions engaged in efforts to prevent youth alcohol, tobacco, illicit drug, and inhalant abuse.

Drug Education for Youth (DOJ and DOD)
$\$ 1,869,136$ Community coalitions

$\$ 1,869,136$ Community coalitions

Youth ages 9 to 12

\section{To support a} multiphased program for 9- to 12-year-olds to reduce risk factors that scientific research has linked to adolescent substance abuse, including tobacco use, school failure, delinquency, and violence. 
Appendix II: Selected Federal Programs That Address or Can Address Tobacco Prevention

and Reduction among Youth

\begin{tabular}{|c|c|c|c|c|}
\hline Program & $\begin{array}{r}\text { Funding fiscal } \\
\text { year } 2002^{\mathrm{a}}\end{array}$ & Eligible applicants ${ }^{b}$ & $\begin{array}{l}\text { Targeted } \\
\text { beneficiaries }\end{array}$ & $\begin{array}{l}\text { Grant program } \\
\text { description }\end{array}$ \\
\hline $\begin{array}{l}\text { Safe Schools/Healthy Students } \\
\text { (Education, HHS and DOJ) }\end{array}$ & $\$ 171,588,449$ & $\begin{array}{l}\text { Local education agencies } \\
\text { in partnership with local } \\
\text { public mental health } \\
\text { authorities, and law } \\
\text { enforcement agencies }\end{array}$ & $\begin{array}{l}\text { Preschool and school- } \\
\text { age children, } \\
\text { adolescents, and their } \\
\text { families who are at } \\
\text { risk of being involved } \\
\text { in drug abuse, or } \\
\text { violence as } \\
\text { perpetrators, victims, } \\
\text { or witnesses }\end{array}$ & $\begin{array}{l}\text { To assist school } \\
\text { districts in developing } \\
\text { comprehensive } \\
\text { services to promote } \\
\text { healthy childhood } \\
\text { development and } \\
\text { prevent violence and } \\
\text { alcohol and other drug } \\
\text { abuse, including } \\
\text { tobacco use. }\end{array}$ \\
\hline
\end{tabular}

Sources: Agency program officials, agency documents, and the Catalog of Federal Domestic Assistance.

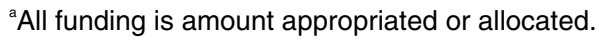

"In this column, the term "state" includes the District of Columbia and some or all of the following: the Commonwealth of Puerto Rico, the U.S. Virgin Islands, the Republic of Palau, the Federated States of Micronesia, and other territories or possessions of the United States unless otherwise noted.

${ }^{\mathrm{c} T}$ Total block grant funding for chronic disease programs was $\$ 49,601,321$.

${ }^{d}$ State-reported planned expenditures for fiscal year 2002. 


\section{Appendix III: Comments from the Department of Health and Human Services}

Washington, D.C. 20201

Ms. Marjorie E. Kanof

Director, Health Care - Clinical Health Care Issues

United States General

Accounting Office

Washington, D.C. 20548

Dear Ms. Kanof:

Enclosed are the Department's comments on your draft report entitled, "Tobacco Use and Public Health: Federal Efforts to Prevent and Reduce Tobacco Use Among Youth." The comments represent the tentative position of the Department and are subject to reevaluation when the final version of this report is received.

The Department also provided several technical comments directly to your staff

The Department appreciates the opportunity to comment on this draft report before its publication

Sincerely,

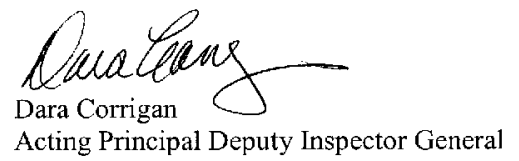

Enclosure

The Office of Inspector General (OIG) is transmitting the Department's response to this draft report in our capacity as the Department's designated focal point and coordinator for General Accounting Office reports. OIG has not conducted an independent assessment of these comments and therefore expresses no opinion on them. 
Comments of the Department of Health and Human Services on the U.S. General Accounting Office's Draft Report, “Tobacco Use and Public Health: Federal Efforts to Prevent and Reduce Tobacco Use Among Youth" (GAO-04-41)

The Department of Health and Human Services (HHS) appreciates the opportunity to comment on the above-referenced draft report. HHS recognizes the importance of addressing tobacco use among youth, and is pleased that efforts such as the National Tobacco Control Program were reviewed and included as examples of the Department's activity and leadership in this area. The report is very informative of Federal efforts to prevent and reduce youth smoking, and HHS appreciates the extensive efforts that the General Accounting Office (GAO) expended in assembling this thorough overview of nicotine and tobacco activities related to youth.

However, the draft report appears to have missed a substantial element of HHS tobacco prevention by not including programs within the Centers for Medicare \& Medicaid Services (CMS). Within Medicaid, the Federal guidelines specifically permit coverage of tobacco cessation therapy with a particular focus on children (and on pregnant women). A State Medicaid Director letter on the CMS web site (www.cms.hhs.gov/states/letters/smd01051.asp), notes that: "States are required to cover smoking cessation drug therapy when it is determined medically necessary for eligible individuals under age $21 . "$ The letter continues by noting that: "States also are required as part of EPSDT screening component to discuss tobacco use and provide counseling for smoking cessation to children and adolescents at appropriate ages." Therefore, the draft report would have benefited from including a discussion of CMS programs as well.

In several places (e.g., pages 4,18 , and 23 ), the draft report refers to HHS officials commenting that coordination between multiple HHS agencies across programs can be difficult because of differing missions and priorities. Challenges experienced by other Departments, if any, are not noted. If $\mathrm{GAO}$ has information related to coordination challenges in other Departments, the inclusion in the report of this kind of information may create more of a balance. In addition, HHS believes that these kinds of comments are useful only if presented in the context of a background in which specific examples are cited to indicate how real roadblocks, if any exist, may be removed. 


\title{
Appendix IV: GAO Contact and Acknowledgments
}

\author{
GAO Contact James O. McClyde, (202) 512-7152
}

Acknowledgments

In addition to the person named above, contributors to this report were Alice London, Donna Bulvin, Krister Friday, and Lawrence Solomon. 


\section{GAO's Mission}

The General Accounting Office, the audit, evaluation and investigative arm of Congress, exists to support Congress in meeting its constitutional responsibilities and to help improve the performance and accountability of the federal government for the American people. GAO examines the use of public funds; evaluates federal programs and policies; and provides analyses, recommendations, and other assistance to help Congress make informed oversight, policy, and funding decisions. GAO's commitment to good government is reflected in its core values of accountability, integrity, and reliability.

\section{Obtaining Copies of GAO Reports and Testimony}

The fastest and easiest way to obtain copies of GAO documents at no cost is through the Internet. GAO's Web site (www.gao.gov) contains abstracts and fulltext files of current reports and testimony and an expanding archive of older products. The Web site features a search engine to help you locate documents using key words and phrases. You can print these documents in their entirety, including charts and other graphics.

Each day, GAO issues a list of newly released reports, testimony, and correspondence. GAO posts this list, known as "Today's Reports," on its Web site daily. The list contains links to the full-text document files. To have GAO e-mail this list to you every afternoon, go to www.gao.gov and select "Subscribe to e-mail alerts" under the "Order GAO Products" heading.

\section{Order by Mail or Phone}

The first copy of each printed report is free. Additional copies are $\$ 2$ each. A check or money order should be made out to the Superintendent of Documents. GAO also accepts VISA and Mastercard. Orders for 100 or more copies mailed to a single address are discounted 25 percent. Orders should be sent to:

\section{U.S. General Accounting Office \\ 441 G Street NW, Room LM \\ Washington, D.C. 20548}

$\begin{array}{lll}\text { To order by Phone: } & \text { Voice: } & \text { (202) } 512-6000 \\ & \text { TDD: } & (202) 512-2537 \\ & \text { Fax: } & \text { (202) } 512-6061\end{array}$

\section{To Report Fraud, Waste, and Abuse in Federal Programs} Contact:

Web site: www.gao.gov/fraudnet/fraudnet.htm E-mail: fraudnet@gao.gov Automated answering system: (800) 424-5454 or (202) 512-7470 